Science, Technology and Development 34 (4): 255-259, 2015

ISSN 0254-6418 / DOI: 10.3923/std.2015.255.259

(C) 2015 Pakistan Council for Science and Technology

\title{
Identification of Local Climate Change Adaptation Strategies for Water Management in Districts Attock and Chakwal, Pakistan
}

\author{
${ }^{1}$ Nusrat Habib, ${ }^{1}$ Muhammad Zubair Anwer, ${ }^{1}$ Sobia Naheed and ${ }^{2}$ Tariq Hassan \\ ${ }^{1}$ Social Sciences Research Institute, National Agricultural Research Centre, Islamabad, Pakistan \\ ${ }^{2}$ Sciences Research Institute, National Agricultural Research Centre, Islamabad, Pakistan
}

\begin{abstract}
Climate change is predicted to have the main impact on agriculture, economy and livelihood of the populations of under-developed world and mainly in rainfed area of Pakistan, which generally called as Pothwar region. To improve the knowledge in this respect and guide policy making for adequate and relevant adaptation strategies, 60 farmers were interviewed in two districts, namely Attock and Chakwal. Farmers were asked closed and open-ended questions about farm activities, farmer climate knowledge and perceived climate change and adaptation strategies for water management. About $68 \%$ of the respondents perceived that Climate Change (CC) resulted in increase in temperature and 55\% agreed on low rainfall in the study area. About $81.66 \%$ respondents were agreed on water stress in the study area. About $55 \%$ perceived that climate change reduced yield of crops and almost $75 \%$ respondents were rely on only rain water for crops. Copping strategies for these issues were that respondents favored the planting of drought resistant/tolerant crop varieties, planting of many different types of crops (mixed-cropping) and planting of pest/disease resistant/tolerant crop varieties. The farmers agreed that straw mulching of crops to reduce water loss (33.02\%) and increase in use of organic manure (57.13\%) are coping strategies to reduce or alleviate the effect of climate change.
\end{abstract}

Key words: Climate change, water management, Attock, Chakwal, Pakistan

\section{INTRODUCTION}

The earth's climate is subject to change by both natural and anthropogenic influences. Climate change will have far-reaching consequences for agriculture that will disproportionately affect the poor, who depend on agriculture for their livelihoods (World Bank, 2007). Such as climate related crop failures, fishery collapses and livestock deaths already cause economic losses and undermine food security and these are likely to become more severe as global warming continues (Nelson et al., 2009; RAE, 2010; Agha, 2009). Climate change is expected to impact both on rainfed and irrigated agriculture (UN Water Policy, 2011; ICIMOD., 2007).

Similarly agriculture is the most vulnerable sector to climate change. Agriculture productivity is being affected by a number of factors of climate change including rainfall pattern, temperature hike, changes in sowing and harvesting dates, water availability and land suitability. The largest impact in the agricultural sector is likely to be felt in irrigation, as water supply becomes scarcer in some areas and more subject to extreme variations (Ziska, 2011). Furthermore according to Doll (2002), temperature indirectly affects the water requirement from the crop as a warmer weather means a higher evapotranspiration from the plant (Kundzewicz et al., 2007). All these factors which caused less water availability can change yield and agricultural productivity (Kaiser et al., 1993).

Pakistan is basically an agricultural country, where out of 22 million hectares (Mha) cultivated land, about $25 \%$ area is rainfed and depends on rainfall directly or indirectly for crop production. Water is a scarce source due to various management problems and great difficulties arise in raising crops/plants due to uncertain water supplies. Most of the agriculture in these areas, especially Pothwar Plateau, is practiced through obsolete irrigation and cropping methods. As a result, the crop productivity and water use efficiency are very low. Moreover, poor land and water management is also contributing in the degradation of natural resources where erosion of productive lands is a major threat. Pakistan being an agrarian country heavily depends upon the water sources (Ahmad et al., 2003; Razzaq et al., 2002). The climate of rainfed area can be classified on the basis of rainfall distribution patterns into three zone, i.e., (1) Low rainfall zone receiving less than $500 \mathrm{~mm}$ rainfall, (2) Medium rainfall zone receiving $500-750 \mathrm{~mm}$ rainfall and (3) High rainfall areas receiving more than $750 \mathrm{~mm}$ rainfall annually (Beg et al., 1985; Anonymous, 2009; Abdullah, 1987). 
This may be viewed from the fact that during the recent drought in the country, the Pothwar region was the most affected causing huge loss of crops and livestock. Therefore, there is an emerging need to conduct a comprehensive study on a holistic manner taking the whole Pothwar including high, medium and low rainfall zones. This study aims to assess the local climate change adaptation strategies for water resources and water management issues in Pothwar region. Efforts will be made to link the climate change impacts with the actual field Conditions. The study will be done by social scientist in collaboration with climate change, alternative energy and water resources institute (CAERI, NARC).

This study will investigate the local indigenous adaptation practices for water management with reference to climate change.

Objectives: The specific objectives of the study are:

- To study the existing climate change adaptation strategies for water management in the study area

- To identify positive and negative facts associated with the local climate change adaptation strategies for water management in the study area

\section{MATERIALS AND METHODS}

This study covered two major districts of Pothwar region, namely Attock and Chakwal. A total 60 respondents were interviewed. Data was summarized, entered in SPSS software and simple descriptive and Chi-Square analysis applied.

Chi-square test: Chi-square was applied to find out the relationship between certain independent and dependent variables.

The chi-square was calculated with following equation:

$$
\chi^{2}=\sum \frac{(\mathrm{fo}-\mathrm{fe})^{2}}{\mathrm{fe}}
$$

Where:

$\mathrm{O}=$ Observed

$\mathrm{E}=$ Expected value

$\mathrm{S}=$ Sum of value

In order to judge the significance of results, the calculated values of chi-square were compared with the tabulated value at a given degree of freedom. The result was considered significant of the calculated value of chi-square was greater than the table value otherwise it was regarded non-significant.

\section{RESULTS AND DISCUSSION}

General farmer's characteristics: On average age of the respondents was 43.00 in district Attock and 47.21 in district Chakwal and overall 41.03. Farming experience on average in Attock, Chakwal and overall were 31.23, 26.19 and 29.21, respectively. Average household was 6.11 in the study area. Education of the respondents in Attock and Chakwal was 5.16 and 7.27, respectively. Lastly total own land average was 4.49 acres in the study area with 4.14 in district Attock and 5.17 in district Chakwal (Table 1).

General climate variability and change: Almost all the farmers were interviewed believe there had been changed in the overall climate pattern. Mostly farmers respond that there was rising temperature and low rainfall in the study area by 68.33 and $55.00 \%$, respectively. Major change in the area was water stress $(81.66 \%)$ and it was correlated with rising temperature and low rainfall. The droughts, strong winds, cold spells more, warm spells more and erratic rainfall by 31.66, 51.66, 45.00, 56.66 and 58.33\%, respectively (Table 2).

Change in rainfall pattern: The summer rainfall was perceived by farmers to be later nowadays than before (Table 3). Almost 65 and 85\% farmers from district Attock and Chakwal perceived that summer rainfall was late, respectively. While in case of summer duration in both districts farmers perceived that summer duration increased. The number of rainfall events during winter season was perceived to have decreased (62.50 and 65\% in Attock and Chakwal) with the number of dry spells perceived to have increased (Table 3).

Change in temperature: Farmers perceived that generally the number of hot days, summer temperature and winter temperature had increased. The number of chilling days was mentioned to have decreased in the

Table 1: Averages of general farmer's characteristics

\begin{tabular}{lrrr}
\hline Variable & Attock & Chakwal & Overall \\
\hline Age (years) & 43.00 & 47.21 & 41.03 \\
Farming experience (years) & 31.23 & 26.19 & 29.21 \\
Household size (Numbers) & 7.04 & 5.15 & 6.11 \\
Education (years) & 5.16 & 7.27 & 7.55 \\
Total Own land (Acres) & 4.14 & 5.17 & 4.49 \\
\hline
\end{tabular}

Table 2: Aspects of percentage climate change

\begin{tabular}{lclc}
\hline Variable & Mean & Variable & Mean \\
\hline Rising temperature & $68.33(41)$ & Erratic Rainfall & $58.33(35)$ \\
Droughts & $31.66(19)$ & Low Rainfall & $55.00(33)$ \\
Strong wind & $51.66(31)$ & Water stress & $81.66(49)$ \\
Cold spells more & $45.00(27)$ & Warm spells more & $56.66(34)$ \\
\hline
\end{tabular}


Sci. Technol. Dev., 34 (4): 255-259, 2015

Table 3: Farmers' perceived change in the rainy season pattern (\%)

\begin{tabular}{lcc}
\hline & Attock (40) & Chakwal (20) \\
\hline Summer rainfall & $7.50(3)$ & $00.00(0)$ \\
Early & $65.00(26)$ & $85.00(17)$ \\
Late & $27.50(11)$ & $15.00(3)$ \\
No Change & & \\
Winter Rainfall & $15.00(6)$ & $05.00(1)$ \\
Early & $62.50(25)$ & $65.00(13)$ \\
Late & $22.50(9)$ & $30.00(6)$ \\
No Change & & \\
Summer season duration & $10.00(4)$ & $00.00(0)$ \\
Decreased & $85.00(34)$ & $85.00(17)$ \\
Increased & $05.00(2)$ & $15.00(3)$ \\
No Change & & \\
Dry Spell Frequency & $02.50(1)$ & $10.00(2)$ \\
Decreased & $82.50(33)$ & $65.00(13)$ \\
Increased & $15.00(6)$ & $25.00(5)$ \\
No Change &
\end{tabular}

Table 4: Farmers’ perceived change in temperature pattern (\%)

\begin{tabular}{lcc}
\hline & Attock & Chakwal \\
\hline Summer temperature & & \\
Decreased & $17.50(7)$ & $10.00(2)$ \\
Increased & $70.00(28)$ & $75.00(15)$ \\
No Change & $37.50(15)$ & $15.00(3)$ \\
Winter temperature & & \\
Decreased & $10.00(4)$ & $00.00(0)$ \\
Increased & $70.00(28)$ & $95.00(19)$ \\
No Change & $20.00(8)$ & $5.00(1)$ \\
Hot days & & \\
Decreased & $2.50(1)$ & $00.00(0)$ \\
Increased & $80.00(32)$ & $100.00(20)$ \\
No Change & $17.50(7)$ & $00.00(0)$ \\
Chilling days & & \\
Decreased & $77.50(31)$ & $95.00(19)$ \\
Increased & $5.00(2)$ & $00.00(0)$ \\
No Change & $17.50(7)$ & $5.00(1)$ \\
\hline
\end{tabular}

Table 5: Farmers’ crop management adaptations (\%)

\begin{tabular}{lcc}
\hline \multicolumn{1}{l}{ Sowing date } & Attock & Chakwal \\
Early & $45.00(18)$ & $5.00(1)$ \\
Late & $47.50(19)$ & $80.00(16)$ \\
No change & $07.50(3)$ & $15.00(3)$ \\
Crop productivity & & \\
Increased & $92.50(37)$ & $65.00(13)$ \\
Decreased & $2.50(1)$ & $15.00(3)$ \\
No change & $5.00(2)$ & $20.00(4)$ \\
Crop varity & & \\
Changed & & \\
No changed & $85.00(34)$ & $65.00(13)$ \\
\end{tabular}

study area (Table 4). There was generally an association between the changes in temperature (hot, cool days and months) and country, except the temperature trend itself. Farmers generally perceived no change in the hottest and coolest months of the year.

Farmers' adaptation strategies to climate change: Farmers' adaptation strategies included crop, soil fertility and soil water management practices.
Table 6: Ground water availability and source of irrigation

\begin{tabular}{lccr}
\hline Specification & Min. & Max. & \multicolumn{1}{c}{ Mean } \\
\hline Ground water table (feet) & 50 & 550 & 270.31 \\
Ground water table (feet) (10 years before) & 20 & 300 & 176.34 \\
Change in depth (Inch/feet) & 10 & 240 & 76.88 \\
\hline
\end{tabular}

Crop management: As an adaptation to late rain onset the majority of farmer respondents delay sowing dates (Table 5). This change in sowing date was more adopted in the district Chakwal (80\%) as compared to the district Attock (47.50\%). In case of crop productivity district Attock crop productivity increased more than district Chakwal.

The majority of farmers changed crop variety in Attock (85\%) and Chakwal (65\%) and they adopted high yielding varieties on their fields and in a result they gain more productivity than ever before (Table 5).

Water management: Farmers perceived that change in ground water-table mean was 76.88 feet. Currently ground water-table mean value was 270 feet with minimum of 50 feet and maximum of 550 feet. While ten years back on average ground water-table was 176 feet with minimum of 20 feet and maximum of 300 feet (Table 6).

Water management practices: Farmers perceived that on average, $43 \%$ farmers were aware about water harvesting technique and on average 31.07 farmers were practicing this technology. The practice of development and maintenance of watersheds were known by $21 \%$ farmers and practiced by 11.13 farmers in the study area. The extraction of ground water technology was known by $83 \%$ respondents and used by 69.25 respondents. Drainage management was known by $61 \%$ farmers and used by 43.27 farmers. Use of sprinkler and drip irrigation was known by $83 \%$ and $74 \%$ farmers but used by only 6.00 and 13.11 farmers due to high cost (Table 7).

Mostly famers were managed external water for their crop by depending upon rain water (75\%) and farm ponds (27\%). Farmers were improving water holding capacity, using manure applications, tied ridges, straw mulching and earthen contour bunds by 57, 41, 33 and 11\%, respectively. While they were increasing plant water uptake capacity, using dry planting (41\%), optimum crop rotation (40\%), pest control (26\%), improved crop varieties (73\%) and intercropping techniques (14\%) on their fields (Table 8).

Chi-square and correlation analysis: The Chi-square analysis confirms that significant differences exist in the study area between climate change variables and crop 
Sci. Technol. Dev., 34 (4): 255-259, 2015

Table 7: Water management practices

\begin{tabular}{lcc}
\hline Practices & Whether aware (Y/N) percent & Are you practicing percent \\
\hline Water harvesting & 43.00 & 31.07 \\
Development and maintenance of watersheds & 21.00 & 11.13 \\
Extraction of ground water & 83.00 & 69.25 \\
Drainage management & 61.00 & 43.27 \\
Use of sprinklers & 83.00 & 6.00 \\
Use of drip irrigation & 74.00 & 13.11 \\
\hline
\end{tabular}

Table 8: Factors influencing the harvesting system, water holding and water uptake capacity

\begin{tabular}{lccc}
\hline How you manage external water for harvesting systems please specify management practices (\%)? & \\
Farm ponds & $27.50(11)$ & Subsurface tanks & $02.50(1)$ \\
Subsurface mini dam & $07.50(3)$ & Depend upon rain & $75.00(45)$ \\
How you improve soil water holding capacity & please specify management practices & (Mean)? & \\
Tied ridges & 41.11 & Earthen contour bunds & 11.07 \\
Straw mulching & 33.02 & Manure applications & 57.13 \\
How you increase plant water uptake capacity systems please specify management practices (\%)? & 72.83 \\
Dry planting (early) & 41.23 & Improved crop varieties & 13.79 \\
Optimum crop rotation & 39.76 & Intercropping & \\
Pest control & 26.57 & & \\
\hline
\end{tabular}

Table 9: Relationship between perception of climate change with crop productivity and socio economic variables (a chi-square analysis)

\begin{tabular}{lrr}
\hline Management practices & Chi-square & Significance level \\
\hline Rising temperature vs crop productivity & 70.24 & 0.019 \\
Low Rainfall vs crop productivity & 39.23 & 0.011 \\
Change in cropping pattern due to climate change & 103.22 & 0.000 \\
Water management and crop yield & 11.79 & 0.049 \\
Climate change and crop rotation & 14.37 & 0.017 \\
Water management and experience & 3.09 & 0.079 \\
Climate change and improved crop varieties & 27.78 & 0.001 \\
Droughts and crop productivity & 84.13 & 0.003 \\
Awareness and crop productivity & 2.13 & 0.148 \\
High rainfall and crop productivity & 14.89 & 0.061 \\
\hline
\end{tabular}

productivity and socio economic variables. For example, except Water management and experience and Awareness and crop productivity, all the other variables mentioned in Table 9, are highly significant and have strong variation between climatic factors and crop productivity and socio economic variables (Table 9). Correlation analysis showed negative association between increase in temperature and decrease in rainfall affect the crop productivity significantly in the study area.

About $68 \%$ of the respondents perceived that climate change resulted in increase in temperature on similar lines, study declared that the surface temperature of Pakistan is rising rapidly over the years with higher ratio. About 55\% farmers agreed on low rainfall in the study area on similar lines, Latif and Tariq (2006) stated the average rainfall decrease in Pakistan and they also concluded that the rain is erratic and insufficient for crop growth in Pakistan. About $81.66 \%$ respondents were agreed on water stress in the study area. About 55\% perceived that climate change reduces yield of crops and almost $75 \%$ respondents were rely on only rain water for crops, similarly, Heisey and Edmeades (1999) described that water stress due to climate change damaged the crops yield when it rose at reproductive stage of crop's life cycle.
The farmers agreed that straw mulching of crops to reduce water loss (33.02\%) and increase in use of organic manure $(57.13 \%)$ are coping strategies to reduce or alleviate the effect of climate change. Many studies show that crop yields were increased through straw mulching and with the use of organic manure (Stroosnijder, 2003).

\section{CONCLUSION}

The subject study found that crop managements strategies (change in sowing date and crop cultivar) were more adopted than soil fertility and soil water management's practices due to socio-economic constraints associated with the latter ones. Moreover study found that many farmers were still hesitating to adopt the adaptation strategies which highlight the need to evaluate them so as to facilitate decision making. Efforts should be geared towards developing and making available crop varieties and livestock breeds that are tolerant to adverse conditions associated to climate change such as diseases, flood, drought and temperature. A multi-media enlightenment campaign of the effects and possible coping strategies should be adopted by all tiers of government to reach the farmers using the available extension structures. 
Sci. Technol. Dev., 34 (4): 255-259, 2015

\section{REFERENCES}

Abdullah, M., 1987. Dry land farming in Punjab. Agriculture Department, Government of the Punjab, pp: 4-5.

Agha, A.A., 2009. Indus basin water resource. Tiempo No. 70, A Bulletin on Climate and Development, USA., January 2009.

Ahmad, S., A. Bari and A. Muhammad, 2003. Climate change and water resources of Pakistan: Impact, vulnerabilities, coping mechanisms. Proceedings of the Year End Workshop on Climate Change and Water Resources in South Asia, January 7-9, 2003, Kathmandu, Nepal.

Anonymous, 2009. Agricultural statistic of Pakistan. Ministry of Food and Agriculture, Government of Pakistan, Islamabad, Pakistan.

Beg, A.R., M.S. Baig, Q. Ali and C.M.A. Khan, 1985. Agro-ecological zonation of potwar: A-wheat, B-maize. National Agricultural Research Centre, Islamabad, Pakistan Forest Institute, Peshawar and Soil Survey of Pakistan, Lahore.

Doll, P., 2002. Impact of climate change and variability on irrigation requirements: A global perspective. Clim. Change, 54: 269-293.

Heisey, P.W. and G.O. Edmeades, 1999. Maize production in drought-stressed environments: Technical options and research resource allocation. Part 1 of CIMMYT 1997/98 World Maize Facts and Trends, CIMMYT, Mexico, D.F., pp: 1-68.

ICIMOD., 2007. Climate change and the Himalayas. Sustainable Mountain Development in the Greater Himalayan Region, Report No. 53, International Centre for Integrated Mountain Development (ICIMOD), Hindu Kush, Himalayas.

Kaiser, H.M., S.J. Riha, D.S. Wilks, D.G. Rossiter and R.K. Sampath, 1993. A farm-level analysis of economic and agronomic impacts of gradual climate warming. Am. J. Agric. Econ., 75: 387-398.
Kundzewicz, Z., L. Mata, L. Arnell, P. Doll and P. Kabat et al., 2007. Fresh Water Resources and their Management. In: Climate Change 2007: Impacts, Adaptation and Vulnerability: Contribution of Working Group II to the 4th Assessment Report of the IPCC, Parry, M.L., O.F. Canziani, J.P. Palutikof, P.J. van der Linden and C.E. Hanson (Eds.). Chapter 3, Cambridge University Press, Cambridge, UK., ISBN-13: 9780521880107, pp: 173-210.

Latif, M. and A. Tariq, 2006. Indus basin irrigation system of Pakistan: A food engine. Centre of Excellence in Water Resources, UET, Lahore.

Nelson, G.C., M.W. Rosegrant, J. Koo, R. Robertson and T. Sulser et al., 2009. Climate change: Impact on agriculture and costs of adaptation. Food Policy Report No. 19, International Food Policy Research Institute (IFPRI), Washington, DC., USA.

RAE., 2010. Global Water Security an Engineering. The Royal Academy of Engineering, London, UK.

Razzaq, A., M. Munir, N.I. Hashmi, P.R. Hobbs and A. Majid, 2002. Current management practices for wheat production in a rainfed agro-ecological zone in Northern Punjab. Pak. J. Agric. Res., 17: 201-205.

Stroosnijder, L., 2003. Technologies for improving green water use efficiency in West Africa. Proceedings of the Water Conservation Technologies for Sustainable Dryland Agriculture in Sub-Saharan Africa Symposium and Workshop, April 8-11, 2003, Bloemfontein, South Africa.

UN Water Policy, 2011. Climate change adaptation: The pivotal role of water. http://www.unwater.org/ downloads/unw_ccpol_web.pdf.

World Bank, 2007. Population issues in the 21st century: The role of the World Bank. HNP Discussion Paper, Report No. 40583, The World Bank, Washington, DC., USA., April 2007.

Ziska, L.H., 2011. Climate Change, Carbon Dioxide and Global Crop Production: Food Security and Uncertainty. In: Handbook on Climate Change and Agriculture, Dinar, A. and R.O. Mendelsohn (Eds.). Edward Elgar Publishing Ltd., Cheltenham UK., ISBN-13: 9780857939869, pp: 9-31. 